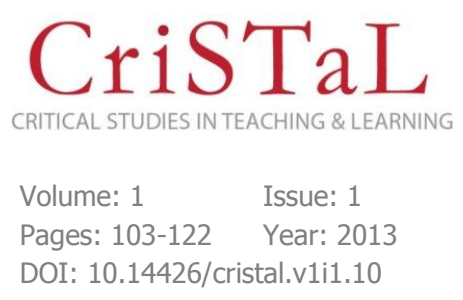

\title{
Risk in Postgraduate Writing: Voice, Discourse and Edgework
}

Lucia Thesen ${ }^{1}$

\begin{abstract}
This paper brings writing into the contested space of research and knowledge-making in South Africa. An often hidden dimension of research is that it has to find expression in a written product, increasingly in English. This creates challenges for both students, who have developed writing identities in other domains, disciplines and languages, and also supervisors and journal editors who are gatekeepers for the making of new knowledge. In a competitive and uncertain climate where discourses of risk management play an increasingly important part, people tend to play it safe when it comes to writing, conforming to a narrow image of scientific writing. This has consequences for knowledge-making as students often set aside the experiences, allegiances and styles they have developed along the way. Drawing on data from an international publishing project on risk in academic writing, the paper explores dilemmas around the process of research writing. These instances make the contradictions and tensions faced by writers and gatekeepers central, highlighting the importance of voice and risk. Both voice and risk are explored experientially and theoretically, with the emphasis on the potentials of risk. The concept of risk, not as risk management, but as risk-taking, offers new ways of thinking about writing that brings the decisions that writers and readers make to the fore. A focus on risk has the potential to offer new understandings about the changing landscapes in which writers and readers weigh up their options against notions of what is 'normal'. Finally I suggest edgework as a productive concept that can take work on risk forward in both research and pedagogy.
\end{abstract}

Keywords: edgework; postgraduate; research; risk; voice; writing

\footnotetext{
${ }^{1}$ Corresponding author: lucia.thesen@uct.ac.za
} 


\section{Introduction}

While universities have always been sites of contestation and competing ideologies, we are in a particularly important phase at this point in our history, as South Africa struggles to shake off the legacy of apartheid and to join the fast-changing and competitive world of the global university. Research is seen as central to the university's role, whether in the name of enhanced competitiveness in the global rankings or to contribute to national development and the big issues of our time. Expressing its faith in the power of research to contribute to redress and development, the National Research Foundation (NRF) has announced a five-fold increase in the number of postgraduates by 2025 , as a driver of a commitment to social justice and the narrowing of the poverty gap and inequality (NRF, 2007). But there are deep concerns about how this will be achieved given available resources (Herman, 2011).

This paper introduces the writing of research as an important feature in the drive to increase postgraduate enrolments. There is no research without a written, recognisable product that can travel beyond the laboratory or research site to share and translate insight into knowledge that makes a difference. Writing is often not regarded as central to postgraduate pedagogy. It is usually seen as a matter for undergraduates, and hence of teaching and learning; or it is displaced to the write-up phase, after the real scientific work has been done. But this is changing. 'Internationalisation' which brings with it more mobility between languages, countries as well as domains and disciplines, raises awareness of the challenges of writing in new styles, languages and genres, as students and young researchers transition between contexts. The growing pressure on academics and postgraduates to publish in rated journals also draws attention to these writing challenges. As Lillis and Curry point out in their study of the global politics of publishing in English, the term 'international' has different meanings in different contexts. In publishing, it indexes 'English medium' (2010:6). The problem is compounded by the materiality of writing in any language: most of the time, writing does not travel well. It holds its form, but as Blommaert (2005) reminds us, not its meaning. As I show later in this paper, traveling texts open up communication in some ways, but close it down by producing inequality in other ways. Thus writing, particularly in English, can be seen as a symptom of a stretched and unequal global system.

One of the recent expressions of writing as a symptom of challenges elsewhere, is the outsourcing of support for postgraduate writing. This can be seen in the growing demand for generic (what I call pop-up or 'soundbite') workshops on aspects of research writing. This increase in outsourced help also takes place outside of the university, most notably in the 


\section{Risk in postgraduate writing}

editing industry and surplus of self-help books on how to write your thesis in the shortest possible time (Kamler and Thomson, 2008). These mainly procedural texts, also available on the web, rush in to close a gap; but like fast foods, they cannot deeply satisfy the reader. They don't engage with the deep structure of postgraduate research and its central function, to make new knowledge. This will always involve profound issues of power and authority which are experienced as dilemmas.

In a move to embrace these dilemmas, Chihota (2007) describes the experience of being a postgraduate as 'the postgraduate condition', a pervasive and extended state of being both novice and expert, deeply dependent on precedent, yet required to contribute something new and original; anglicised but not English. Johnson et al (2000) memorably uncover the fantasy of the 'autonomous self' that pervades the 'western' academy - the independent scholar produced through supervision practices in the humanities and social sciences. They trace the antecedents of this autonomous self to the Enlightenment and the 'reasonable man' construct, which emerged from a series of dualisms between rationality and irrationality, autonomy and dependence, minds and bodies, in which a subtle exercise of power creates the independent, knowledge-producing scholar. They show how this construct of the 'always-already' independent self persists in a context of massification of higher education.

A connection between the dominant discourse and writing is made in Cadman's concept of 'divine discourse'. She asks that we find ways to interrogate the taken-for-granted assumptions that underlie postgraduate writing pedagogy and practice. The constraints on what counts as a relevant area of study, the criteria for assessing a thesis or journal article, the available styles, are embedded in an intellectual worldview that 'does not recognise, and therefore cannot know, the limitations of its own taken for granted, almost sacred, understandings, of what constitutes "knowledge" and its expression in the English language' (Cadman, 2003: 1). There are many others now who acknowledge this complex struggle for identity in intertwined and often contradictory discourses that seems to be built in to the postgraduate condition, for example, Kamler and Thomson (2006) and Aitchison and Lee (2006) on research writing, Manathunga (2007) on intercultural supervision. The big sweeps of internationalisation suggest that in South Africa there will be many similarities with experiences elsewhere, but also crucial differences.

Against this background this paper brings the concept of risk - in the sense of taking a risk into the writing space to consider the processes behind the scenes, in which postgraduate writers and their supervisors, mentors and writing peers interact and weigh up what and how 


\section{Thesen}

to write. As I will make clear later, risk is a potentially rich point of entry as it highlights the dilemmas where decisions are made about what will be said in a thesis or journal article, how this will be said and with what audiences in mind. It is essential that we understand these processes of composition as the raw material of new knowledge is forged at this point of commitment to what will go into the written product. There are many writers and supervisors who are not happy with the compromises reached in the written product of a thesis, but the stories and experiences behind this sense of loss tend to remain hidden. These hidden stories of erasure and loss, I believe, then come back to haunt the supervision process.

The term risk is now widely, though controversially, used in managerial discourses in organisations, but needs much greater visibility in how it is experienced by individuals who are not positioned as authoritative and powerful. This in particularly important in postcolonial contexts, what Pratt calls 'contact zones' $(1992 ; 1994)$ in which voices historically separated by geography and history, by slavery, colonialism and for us, apartheid, now intersect. There is a rich tradition of sociological, psychological and cultural theory about risk that may be drawn on, in bringing this across to literacy studies and the sociolinguistics of writing. But as I will make clear later, simply importing these insights is not enough as the term risk is contested, and is unevenly experienced depending on where one is located.

I begin with a series of small cases taken from different chapters in our edited book exploring risk in the writing of research (Thesen and Cooper, 2013). These moments highlight dilemmas and raise questions about the social and historical contexts in which these dilemmas are lived. They illuminate what students, as well as supervisors and editors, set aside or erase in the process of writing, and explore why these decisions are made, with what consequences. I elaborate on one of the cases to explore how two participants described in one of the chapters in the book, Canagarajah and Lee's (2013) analysis of a failed publishing mentorship, use the terms 'voice' and 'risk'. I discuss each term more fully in everyday as well as theoretical ways.

Voice is explored in sociolinguistic traditions that draw on Bakhtin's concept of the utterance (1986). There is no such thing as a 'pure' voice; it is always pulled in multiple directions, a relational concept that highlights both the speaker/writer's 'speech plan', and the authoritative discourses in which it is given meaning, as persuasive, passable, naïve, incoherent. The term 'risk' is shown to be subject to discourse in a range of ways as there is a surge in the use of the term in contemporary 'western' institutions. This surge is related to the prevalence of the discourse of risk management, a trend that South African universities are 
currently experiencing, albeit in different and less intense ways than many of our international 'northern' institutions. The prevalence of this discourse potentially silences difference and creates a climate of playing it safe - what McWilliam calls a 'cold' climate (2009).

In a move to take risk back from the managerial discourses, I propose the notion of risktaking as 'edgework' (Lyng, 1990) as a useful concept for exploring the conceptual edges at which risk and discourse operate. Edgework helps us explore risk-taking 'from below', from the positions of participants on the margins. It draws attention to the choices writers and reader-assessors make as they negotiate the complexities of how to write their research.

\section{Stories from the Contact Zone}

Like many colleagues who have previously worked to demystify undergraduate writing practices, I now spend a lot of my time working with postgraduates and novice researchers on various forms of pedagogy that help writers find or sustain their research voices. I was initially surprised that issues of voice surfaced so strongly for these writers. Surely by the time we are postgraduates, we have developed enough resilience and confidence to push through uncertainty, to trust the relationship between thinking and writing enough to overcome writer's block? Certainly, as a teacher of academic writing for undergraduates, many years ago, I would never have predicted this problem. Theory seemed to promise that over time, and with a deeper immersion in the discipline, our writing voices would become more robust. But this is not necessarily the case. The challenge to make new knowledge is often fraught in the globalising South African university, particularly in a university such as mine, which aspires to an 'Afropolitan' identity, in which knowledge is not simply recycled from the old world, or for the old world, but self-consciously positions itself as African speaking to a sense of place but with a global voice (Price, 2012).

We conceived of a publishing project that would seek to understand these problems of voice. (Thesen and Cooper, 2013). The book began with a collaborative research project established at the University of Cape Town's Centre for Higher Education Development. We became aware that the writing-related challenges encountered by research students were not solely a legacy of South Africa's apartheid past, or an 'African' phenomenon, but were part of a broader concern. The project was, therefore, widened to include colleagues from elsewhere in Africa, and from the United Kingdom, Australia and the United States. The two editors took 
the lead in conceptualising the framework for a book that we hoped would involve a global dialogue around postgraduate writing and pedagogy.

Over time, this project put risk at the centre of the writing experience (Thesen and Cooper, 2013). I select from the richly experiential work in this collection to illustrate the power of risk as a metaphor to bring to the writing of research. I have borrowed from the accounts in these chapters to make my argument. All of these chapters engage in different ways with experience. The tone is set in the quote with which Cooper frames her chapter, citing Michelson, 2004: 27:

Who will be given social agency is both an epistemological and political question. Whose experience of the past and whose vision of the future will be considered credible? Whose modest testimony will be allowed to contribute to a shared understanding of the nature of the world?

Several of the chapters focus on the experiences of adult learners, who under apartheid were denied access to quality education, but experience the research process as a struggle among competing voices, many of which are silenced. An example is Somi Deyi's (2013) account of what she calls 'A lovely imposition' - an opportunity to write her Masters thesis in isiXhosa. Her piece shows the contradictions in multilingual policy, how the challenges of supervision and examination were amplified, yet she does not regret the opportunity, although she had to submit the 'rich and creamy language' of her language of home to scientific discourse.

In Linda Cooper's chapter, she revisits her supervision of adult learners who arrive with a strong sense that 'they have something to say'. In looking back at successive drafts of her student Jerry's work, and through interviewing him, she became aware of how much Jerry felt he had to delete. He grieves that he left out 'the gravy', original quotes from the municipal workers he interviewed, spoken in a bawdy, expressive 'creole' Afrikaans. She is unsettled to hear, years later, that she is partly responsible as his supervisor for this erasure. Cooper asks:

What is lost in this process of negotiation 'between ourselves and our imagined auditors'? In Jerry's case, the deletion of the original quotes in later drafts of his thesis did not merely represent the loss of an empirical window on the kinds of barriers to learning that many workers face; it also represented a loss to our formal knowledge archive of rich insights into the existential world of ordinary workers (2013: 44). 


\section{Risk in postgraduate writing}

These dilemmas - tilting points where we get privileged insight into how participants weigh up their options - raise fascinating questions about knowledge and its relationship to the written product. Often what is at stake, particularly for the novice in the process, cannot easily be named or brought up for discussion. The supervisor often has her eye on assessment: the worst that can happen is that the student fails, which then has an impact on the supervisor's reputation; the student may be balancing much more complex issues, to do with past allegiances and communities (to which many students will return), one's class position, a sense of having 'sold out' to a dominant discourse.

I take an extended look at one of the chapters. This chapter (it is very long - at 17,000 words it is too long for acceptance in a journal) is Suresh Canagarajah and Ena Lee's account of a failed publishing mentorship (Canagarajah and Lee, 2013). Keen to open new spaces in the prestigious US-based TESOL Quarterly journal, Suresh invited new forms and styles when he became journal editor. He saw this as engaging with 'hybridity' - greater openness to alternative discourses, a trend in the academy that he wanted to be part of. Ena's work seemed to fit this new openness perfectly. As an English-speaking Canadian of Chinese origin, she was committed to using narrative to show how discourses of 'race' interacted with the English Second Language construct, an issue she has personally grappled with as a postgraduate student and teacher. Her supervisor encouraged her to submit a paper to the journal. Much later, Ena and Suresh having realised that they could not find common ground because of their different interpretations of events arising from their respective positions as editor and novice researcher, wrote the chapter in our book, exploring a textual history of the article that never got published. The story is briefly reconstructed below.

In framing her initial covering letter to the journal, Ena expresses her doubts about her paper: 'Who will value the story of an insignificant graduate student, let alone a story that may be viewed as just a 'poor me' piece? And will it be seen as 'academic' enough for a highly selective academic journal?' [Italics in the original]. On reading her draft, Suresh is delighted: 'I was surprised to see how close I was to realising some of my publishing dreams so early in my editorial tenure. I had always wanted to publish more diverse genres and research approaches. I was impressed by the timeliness of the subject matter and the audacity of the tone. I initially wanted to hurry the refereeing process as I had the dream of publishing Ena's article as the lead piece in my first issue'. However in spite of this positive evaluation of her work, he does note that aspects of style, for example sections which foreground personal narrative and background theory in footnotes, will be inappropriate for the audience. 
There are other problems too. He chooses sympathetic reviewers who have themselves published unconventional pieces. But the reviewing process is drawn out and gets bogged down.

The reviewers were in broad agreement though giving very different levels of detail in their feedback, one making the comment that : 'In my view, if you do not make such a case then you run the risk of readers dismissing your experiences as anecdotal evidence, and only one person's at that. You also run the risk of presuming that the reasons for valuing one teacher's experiences are self-evident - which is not necessarily the case in a research journal, but certainly not in a journal such as TQ that encompasses a variety of qualitative/quantitative approaches' [Italics added].

Ena was deflated by the feedback and considered withdrawing from the process: 'I felt that trying to qualify my experiences or legitimise them through objective research or "empirical" studies would devalue my story and my point that stories such as mine are often silenced due to 'lack of proof'. It's tiring, the whole 'burden of proof' thing - where minorities always have the burden of proving that they are discriminated against. As I proceeded through the review, I felt more and more discouraged. I contemplated not resubmitting because I was resistant about doing the requested revisions. I was afraid that the change in tone and approach would take away the voice I wanted to use in the paper' [Italics added for voice quote].

Ena duly makes the changes, which are well received. A third reviewer then comes into the picture, and while suggesting relatively minor changes, the actual pages of Ena's draft are covered with 'track changes' edits that effectively change the style of the paper from narrative to argumentation. Unable to negotiate further, and unwilling to alter her preferred voice yet again, Ena withdraws. Suresh, after months and months of what he felt was careful mentoring (and gatekeeping) labour, feels let down. In the rest of their paper they question the concept of hybridity, loosely bandied about as an alternative frame for the emergence of new discourse forms, bringing to it the notion of risk.

Why is risk useful here? At the most obvious level, both Ena and Suresh took risks in making decisions to step outside of their comfort zones. Suresh took the risk of inviting her contribution, knowing that it would be provocative; Ena risked 'failure' in a major journal, but gained something else by holding onto her preferred voice. At this point I am using voice and risk in their 'everyday' meanings. 
The appearance of the terms voice and risk in this textual history is interesting for this paper. To make sense of this, I turn now to consider both terms, beginning briefly with voice, then showing how risk adds further to our understanding.

\section{Losing One's Voice}

Voice is a central concept in the 'academic literacies' tradition (Lillis and Scott, 2007), with its interest in locating academic reading and writing in practices rather than seeing writing as simply a matter of skill, as if skills could be easily transferred across contexts. Voice refers to the way a writer sounds, but how a writer sounds is never treated as an essence, inherent in the writer/speaker. It is always dynamic, inflected and accented in relation to what has come before, and to what is ahead in the anticipated reader (addressee). For Bakhtin

...any word exists in three aspects: as a neutral word of a language, belonging to nobody; as an other's word which belongs to another person and is filled with echoes of the other's utterance; and finally, as my word, for, since I am dealing with it in a particular situation, with a particular speech plan, it is already imbued with my expression (1986: 88).

The notion of voice is controversial (Maybin, 2001). Like Maybin, I identify with Bakhtin's view of voice as a product of struggle. What I write is both my word, with my speech plan and expression, and someone else's word - the word of authority, of constraint, of precedent. Blommaert's concept of voice as semiotic mobility is particularly useful here. He defines it as 'capacity to generate an uptake of one's words as close as possible to one's desired contextualisation' (2005: 69). Under conditions of globalisation, he elaborates on this definition as 'capacity to accomplish functions of linguistic resources translocally, across different physical and social spaces'. These spaces are never empty. They are filled with 'codes, customs, rules, expectations - always somebody else's spaces' (73). One might be regarded as a good writer in Lagos or Durban, but when this writing travels from the margins to the centre of the world system, new functions are attributed, and the work may be read as exotic, strident or out of date. Voice is hard to achieve as 'differences are very quickly (and quite systematically) translated as inequalities between speakers' (71) in the way texts hold their form but not their meaning:

When discourses travel across the globe, what is carried with them is their shape, but their value, but their value, meaning or function do not often travel along with them, 
Value, meaning and function are a matter of uptake, they have to be granted by others on the basis of prevailing orders of indexicality (2005: 72).

The systematic reduction of difference produces inequalities in the ways that institutions exert a centripetal force on the utterance, creating norms for meaning which organise and rank through gate-keeping practices. The bigger the gap between the resources and conditions available for the speaker/writer and the meanings held by norm-making institutions, the greater the risk that one will be misunderstood.

With mobility a key feature of the globally competitive research university, multiply situated perspectives on student voice are important, so that it is possible to keep track of how the brought-along interests of students who have developed confidence on the periphery of the world system, or in domains other than the university - the workplace, industry etc. translate (or not) into academic disciplines and publishing houses, and vice versa. Students who move across disciplines, or universities, or languages, often sound strange in their writing. There may still be an allegiance to a strongly established and by this stage in their academic journeys, embodied disciplinary voice, or a workplace voice that values brevity and efficiency rather than elaboration; international students may be deemed 'uncritical'. Over time these voices wax and wane in how they are woven in to the fabric of convention.

Voice also implies a level of consciousness about what one is doing. The capacity for semiotic mobility refers to a human capability and range that can be exercised to make oneself heard in a range of settings. I believe that this capacity can only be exercised if writers are invited to say what they are doing on all three levels of the Bakhtinian utterance: the dictionary meaning, or referent out there; the plan that I have; and the awareness of what the gatekeepers want. Ena's concern about losing her voice shows acute agency. Her speech plan was to remain 'loyal' to the power of personal narrative to contribute to knowledgemaking, even if she risked being dismissed as anecdotal. We only know about her speech plan because we went behind the text, to discover how she was weighing up her options.

We turn now to the reviewer who warned Ena about what was at stake, what the risks were. But we can't treat the word risk as self-evident. It needs to be situated in discourse(s). The concept is controversial, so needs to be explored more fully before I can use it convincingly in this argument, where it is taken back from its place in managerial discourses and technoscientific disciplines, and used from below, to illuminate dilemmas in the writing of research. 


\section{Running the Risk}

The appearance of the word risk in the reviewer's comments is indicative of a discursive shift in communication. Bernstein (1998) gives us the long view of the changing meaning of risk over the last 300 years or so, noting how it has lost its positive meaning, acquired with the journeys of seafarers of the $16^{\text {th }}$ century, when risk signified the possibility of an 'act of God'. Later modernity offered the possibility of taming uncertainty, fate and chaos, a belief that is now shaky. A good place to start for a recent history is with Zinn's 'Risk as discourse: Interdisciplinary perspectives', the introduction to a special issue of CADAAD journal (Critical approaches to the analysis of discourse across disciplines, 2010). Using corpus linguistics, he notes the increase of the risk semantic in the media and everyday talk, in English, mainly in the UK and US since the Second World War, and that the increase in the use of the term is unexpected, given the overall rise in life expectancy in many post-industrial societies. This leads him to conclude that it is 'not a phenomenon which rests on the objectives state, but an expression of how we think about uncertain futures and possible harm' (106-7), i.e., it needs to be explained through discourse.

The rise in the use of the term, which seems to be supplanting the word 'danger', has attracted scholarly attention beyond the techno-scientific disciplines such as economics, statistics and public health. In a wave of end-of- millennial writing, in sociology, Luhmann (1991), Beck (1992) and Giddens (1991) identified a shift in late modern societies, characterised by a colonisation of the future as the social becomes less tied to tradition and the past. Beck and Giddens called this 'the risk society'. These writers also relate the risk surge to an erosion of faith in the promise of science, and see the risk effect as globalising, potentially reducing difference.

However for Douglas, in anthropology, risk is interesting for how it functions to create difference, in for example the way it has been used in the US to draw a line between 'us' and 'them' (1992). An important strand in the risk literature, which also stresses the gradual change in social regulation and governance, is aligned to Foucault's work on governmentality in which discourse is fundamental to the production of meaning. Unlike those who take a weak constructionist position (see Lupton, 1999 for an analysis of different epistemologies in risk theorisation, from realist to social constructionist), theorists interested in risk and governmentality pay attention to how risk is constructed through processes, technologies and practices of modern institutions since the breakdown of the feudal system in Europe. These processes centre on surveillance, the establishing of pathways, tools and measurement 


\section{Thesen}

practices that shape conduct. Importantly, people on the whole comply with these practices, through self-management, setting goals, motivating themselves, meeting deadlines etc. Foucault calls this self-regulation the flic dans la tete, the 'cop in the head' (See Janks, 2010). This perspective on risk resonates with higher education, where risks as defined by the managerial discourses are less about matters of life and death (though these are crucially the subjects of research), than matters of reputation and rankings. It is interesting to note how over time, and in different places, the notion of the 'at-risk' student has arisen, as a consequence of greater mobility, and in reaction to, the widening participation and internationalisation trends. The term 'at risk' student has been used locally to describe educationally disadvantaged students who are typically black, working class, rural, with English as an additional language, in the historically white, English speaking elite universities. In other parts of the world, the 'at risk' student may have 'learning difficulties' (ADD or dyslexia).

Once a risk has been identified, resources are mobilised to manage the problem. McWilliam shows that doctoral education is caught up in how the university performs through measures that make achievements visible and calculable, naming a 'cold' and reductive notion of risk management that permeates doctoral education in the 'first world'. She rues the cold climate of risk management, of 'what can go wrong and what systems are needed to guard against such possibilities' (2009: 192). We can thus track the emergence of risk objects - things that might go wrong and end up in a law court. Plagiarism has to some extent become a risk object; the same thing may be happening to ethics through the elaborate semi-legal processes of seeking ethics clearance. This makes the proposal a less tentative genre than it used to be.

There are many interesting aspects to the theorisation of risk in discourse. I shall touch on a few here. First, there is the challenge of defining risk. It is a slippery concept, not easy to tie down technically and rationally (though there is a huge industry that attempts to do this, perpetuating what Reddy calls 'the myth of calculability', in Lupton, 1999: 7) A definition of risk comes from Luhmann: 'It is [... ] a matter of a decision that, as can be foreseen, will be subsequently regretted if a loss that one had hoped to avert occurs' (2002: 11). This notion of risk emphasises that it always involves a decision, a moment of weighing up in which the risk taker or -maker consciously makes a choice to do one thing rather than another. There will always be contestation around this, depending on one's position. 


\section{Risk in postgraduate writing}

The student designated at risk may see herself as a high achiever. While there is always a reference to the real (the factual) at the first level, risk becomes most interesting to us as a second order phenomenon: it involves 'multiple contingency, which consequently offers different observers differing perspectives' (2002: 16). This opens it up for critical study, as it sheds light on what is regarded as the institutional 'normal'. So in taking a risk, Jerry (in Cooper's chapter) decides not to include the raw voices of the workers he interviewed. Deyi's supervisors took different kinds of risks in inviting her to write her thesis in isiXhosa. She responded. She took a risk by including the 'rich and creamy' metaphors in her drafts, but her second supervisor insisted that she should strive to sound scientific. Ena Lee, also invited to contribute to an alternative form, submits her article to TESOL Quarterly using a narrative style; she comes up against a barrier, the scientific requirements expressed in the words of the reviewer. The multiple contingencies can be seen in these examples. We can also see here that it is the reviewer who uses the language of risk, 'You run the risk'. Even if things go wrong, the reviewer has pointed out the possibilities and has thus acted correctly; by naming risk, she has inoculated herself against blame.

Like the journal reviewer above, it is usually those in relatively powerful positions who can best articulate the risks within the managerial discourse. This is another feature of the globalising risk discourse - the gap between those who define risk in order to manage institutions and those who live and experience it is growing, as both Beck and Luhmann point out. This is a crucial issue in the changing university. If we are to have empirical studies that bring risk to the surface, then people who are novice, whether students or supervisors, need to be able to articulate decisions reflexively. As Caplan says, "knowledge assumes great significance, but knowledge is always contested" (2000: 21).

Another interesting part of the risk phenomenon is that people often 'change their minds' in the way they see risk because there is an important time delay between the decision-making event, and clarity about the loss (or not) incurred by the decision (Luhmann, 2002). This creates an additional kind of contingency. There is a great deal of hindsight when it comes to risk. Something that might appear to be clear-cut to one person in the moment, may well unfold differently over time. So playing the safe option, at the point of decision-making, where something is resisted and experienced as a loss, may look different later on. While Jerry was angry at the time of having to let go of the 'authentic voices' of his co-workers, he 


\section{Thesen}

tells his supervisor much later on, during the interview, that he is planning on writing a book in which he can include 'all those little things that I couldn't use in the thesis'. Ena's story also unfolds differently over time. Her decision to withdraw from TESOL Quarterly is later experienced positively, as she gets to write about it in this chapter, in a genre where the publishers were prepared to take a risk with a long, dialogic and unconventional chapter. This is also important in the long journey of supervision and writing a thesis. The situation will look different at different points in the journey.

\section{Risk-taking from the South}

I have identified some generative elements in the mainstream literature on risk. The problem with these texts that I have been exploring so far is that their theorisation rides on generalisations about 'we' as people who can interpret, strategise and benefit from these formulations of risk - a distinctly middle class 'western' capability requiring particular resources. In a second wave of scholarship on risk, Caplan's ( 2000) 'Risk Revisited' invited contributors to critique the generalisations from the centre, seeking instead studies that show the agency that people on the margins of the world system display in manoeuvring and making sense of contradictions that present as risk. An example is Vera-Sanso's riposte to Beck's stereotyping of poor people (as subject to 'the dictatorship of scarcity'). She analyses risk-talk related to women and health among low-income rural women in India, to show how they use risk-talk to enlarge their sphere of interest.

What might risk mean for us as South Africans in the writing of our research? Soudien suggests that we are in some ways an important social laboratory as we struggle to make sense in a crucible that is 'simultaneously about integration and segregation, tradition and modernity, being safe and unsafe, being well and unwell' and avoid reducing complexity and diversity to the single factor of race (2012: 5). It is crucial that we find new ways to make knowledge, even if this is risky. Some of this is about using theoretical resources differently so that the use of imported theories in the name of internationalisation does not simply reinforce historical patterns of the dominance of 'northern' theory (Connell, 2007; Comaroff and Comaroff, 2012). That is one of the goals of our research on risk in academic writing. In the preface to the collection of narratives about living with risk in South Africa, Nuttall and McGregor (2007) honour a 'second wave' of post-apartheid narratives with their collection of pieces written by journalists and academics writing outside of the constraints of objectivity 
required by their work. These stories take on the idea of risk, exploring questions about living together, the meaning of freedom, studying the lives of others. These are written in the 'warm' registers that invite tilting points and their rich insights, reminding us of older meanings of risk.

Achille Mbembe has also explored new ways of writing from and about postcolonial Africa. In an interview with Isabel Hofmeyr, she asks him about the writing of his book, On the Postcolony, when as she puts it, 'our academic senses are so numbed by the formulaic discourses'. He talks about finding a way to write that is not predetermined by 'both kinds of developmentalism', the imperial discourse which renders the other incapable of agency, or the postcolonial refusal. He favours 'a language that allows its pulse to be felt' (Mbembe and Hofmeyr, 2008: 254).

Not all of us are confident enough to write in these innovative ways. But we do need to understand the nature of the choices postgraduate students are making when they weigh up what they will and won't say, and how to say out, for which audiences. Here I would like to borrow a concept from the risk literature - edgework.

\section{Edgework}

I have described risk as a way of understanding dilemmas as tilting points between self and range of 'others' both animate (people such as teachers, supervisors, mentors), and inanimate (forms of knowledge, styles, languages). The idea of the tilting point can be taken further with the notion of edgework, which Stephen Lyng, borrowing from Hunter S. Thomson, brings to understand the voluntary risk-taking of the individual, despite the increasing public emphasis on risk management in America. For Lyng, edgework is relational, a way of exploring distinctions and thus dilemmas and contradictions. Drawing on traditions that regard the dialectical relationship between spontaneity and constraint as central to human action and meaning, Lyng sees edgework as follows: 'In abstract terms, edgework is best understood as an approach to the boundary between order and disorder, form and formlessness' (1990: 839).

In institutional settings in which constraint is amplified and experienced as distorted, conflict ridden or contradictory, people may seek more spontaneous outlets to provide a sense of play, creativity or flow. For many students and supervisors, writing or supervising a thesis does have the elements of distortion and contradiction, as mentioned earlier in this article. The 


\section{Thesen}

negative images of survival, danger and dysfunction that pervade studies of metaphors in postgraduate experience and the supervisory relationship (Bartlett and Mercer, 2000) point to the potential usefulness of edgework to explore the moving line between flow, spontaneity, emergence and their antithesis of constraint.

The idea of edgework is also productive for writing pedagogy. There is a growing interest in peer based writing groups that are not recycling arid paint-by-numbers approaches to the writing of research - the soundbite approaches mentioned earlier. The groundswell of interest in writing groups which create rehearsal spaces for interdisciplinarity, gender solidarity and laughter, peer-based writing pedagogies described by Aitchison (2009), Chihota and Thesen (forthcoming), Grant (2006) and others, speak to this edgework, as they make space for spontaneity, flow and play, to complement, renew or deflate 'divine discourse'. These groups are not only about spontaneity; the point is that they enable participants to explore the edge between sacred and profane and often open the way for deeply serious and consequential discussions about what knowledge will find its way into our writing, in what forms, for which audiences. These groups have the added benefit of exposing teachers of writing to the lived experience of students from a wide range of backgrounds. Their tensions and dilemmas keep us grounded in research writing practices as they are lived, in the now.

Edgework is also an interesting concept for research, particularly for methodologies for surfacing risk. Researching risk and risk-taking in the lives of writers will not be easy because of the issues of attribution, the time delays, and the gap between experts and novices in marshalling risk-talk that I have touched on above. But in the interests of greater accountability of both writers and readers to the way the world enters research through writing, deep conversations about where the risks lie, what risks are worth taking, and what is at stake, can help to do justice to the complexity of the world we live in, and the responsibility of higher education to be part of this complexity.

This paper has brought risk and risk-taking to the writing of the research. The risk lens extends the concept of voice, a familiar concept in literacy studies and writing pedagogy. Risk can open out rather than close down meaning, since it invites a connection between the messy, contradictory world that we engage with as writers of research, and the institutional discourses that channel these meanings. The gap between the resources available to the next generation of researchers to produce voice and the institution's capacity to hear it, and the gap between those who define and manage risk and those who it experience it in their writing 
journeys, are growing. Researchers, teachers and writers who can do the edgework have a role to play in doing the risky work of making new knowledge.

\section{Bionote}

Lucia Thesen convenes postgraduate writing development initiatives in the Centre for Higher Education Development at the University of Cape Town. She is co-editor of Thesen and Cooper's (2013) Risk in academic writing: Postgraduate students, their teachers and the making of knowledge, Bristol, Multilingual Matters.

\section{Acknowledgements}

I acknowledge funding from the Carnegie Foundation for the African Knowledge Project based in the Research Office at the University of Cape Town. Their support for the publishing project on which this article is based is greatly appreciated.

\section{References}

Aitchison, C., B. Kamler \& A. Lee. (eds.) 2010. Publishing pedagogies for the doctorate and beyond. Abingdon, UK: Routledge.

Aitchison, C. \& A. Lee. 2006. 'Research writing: Problems and possibilities', Teaching in Higher Education, 11(3): 265-278.

Bakhtin, M. 1986. Speech genres and other late essays. Austin: University of Texas Press.

Bartlett, A. \& G. Mercer. 2000. 'Reconceptualising discourses of power in postgraduate supervision', Teaching in Higher Education, 5(2): 195-204.

Beck, U. 1992. Risk society: Towards a new modernity. London: Sage.

Bernstein, P.L. 1998. Against the Gods: The remarkable story of risk. New York: John Wiley.

Blommaert, J. 2005. Discourse: A critical introduction. Cambridge: Cambridge University Press. 
Cadman, K. 2003. 'Divine discourse: plagiarism, hybridity and epistemological racism'. LED 2003: 1st International conference on language, education and diversity. 2003. Online at: http://hdl.handle.net/2440/39833.

Canagarajah, S. \& E. Lee. 2013. 'Negotiating alternative discourses in academic writing and publishing: Risks with hybridity', in L. Thesen \& L. Cooper. (eds). Risk in academic writing: Postgraduate students, their teachers and the making of knowledge. Bristol: Multilingual Matters, 59-99.

Caplan, P. (ed.). 2000. Risk revisited. London: Pluto Press.

Casanave, C.P. \& X. Li. 2008. Learning the literacy practices of graduate school: Insider's reflections on academic enculturation. Ann Arbor: University of Michigan Press.

Chihota, C. 2007. "“The games people play": Taking on postgraduate identities in the context of writer circles', Journal of Applied Linguistics, 4(1): 131-136.

Comaroff, J. \& J.L. Comaroff. 2012. Theory from the South: Or, how Euro-America is evolving towards Africa. Boulder, CO.: Paradigm.

Connell, R. 2007. Southern theory: the global dynamics of knowledge in the social sciences. Sydney: Allen and Unwin.

Cooper, L. 2013. “'Does my experience count?" The role of experiential knowledge in the research writing of postgraduate adult learners', in L. Thesen \& L. Cooper (eds.) Risk in academic writing: Postgraduate students, their teachers and the making of knowledge. Bristol: Multilingaul Matters, 27-47.

Deyi, S. 2013. 'A lovely imposition: The complexity of writing a thesis in isiXhosa', in L. Thesen \& L. Cooper (eds.) Risk in academic writing: Postgraduate students, their teachers and the making of knowledge. Bristol: Multilingaul Matters, 48-58.

Douglas, M. 1992. Purity and danger: An analysis of the concepts of pollution and taboo. London: Routledge.

Giddens, A. 1991. Modernity and self-identity: Self and society in the late modern age. Cambridge: Polity.

Janks, H. 2010. Literacy and power. New York: Routledge.

Johnson, L., A. Lee \& B. Green. 2000. 'The PhD and the Autnonomous Self: Gender, rationality and postgraduate pedagogy', Studies in Higher Education, 25(2): 135-147. 
Kamler, B. \& P. Thomson. 2006. Helping doctoral students write: Pedagogies for supervision. Abingdon, UK: Routledge.

Lillis, T. \& M.J. Curry. 2010. Academic writing in a global context: the politics and practices of publishing in English. Abingdon: Routledge.

Lillis, T. \& M. Scott. 2007. 'Defining academic literacies research: issues of epistemology', Ideology and Strategy, 4(1): 5-32.

Luhmann, N. 2002. Risk: A sociological theory. New Jersey: Aldine Transaction.

Lupton, D. 1999. Risk. London: Routledge.

Lyng, S. 1990. 'A social psychological analysis of voluntary risk-taking', American Journal of Sociology, 95(4): 851-886.

Manathunga, C. 2007. 'Intercultural postgraduate supervision: Ethnographic journeys of identity and power', in D. Palfreyman \& D. McBride. (eds.) Learning and teaching across cultures in higher education. New York: Palgrave, 93-113.

Maybin, J. 2001. 'Language, struggle and voice: The Bakhtin/Volosinov writings', in M. Wetherell, S. Taylor \& S.J. Yates. (eds.) Discourse theory and practice: A reader. London: Sage, 64-71.

Mbembe, A. \& I. Hofmeyr. 2008. 'Writing Africa: Achille Mbembe in conversation with Isabel Hofmeyr', in N. Shepherd \& S. Robins. (eds.) New South African keywords. Johannesburg/Athens, Ohio: Jacana Media/Ohio University Press, 247-254.

McGregor, L. \& S. Nuttall. (eds.) 2007. At risk: Writing on and over the edge of South Africa. Johannesburg and Cape Town: Jonathan Ball.

McWilliam, E. 2009. 'Doctoral education in risky times', in D. Boud \& A. Lee. (eds.) Changing practices of doctoral education. Abingdon: Routledge, 189-199.

Michelson, E. 2004. 'On trust, desire and the sacred: A response to Johann Muller's "Reclaiming Knowledge", Journal of Education, 32: 7-30.

Pratt, M.L. 1992. Imperial eyes: Studies in travel writing and transculturation. First ed. London: Routledge.

Pratt, M.L. 1999. 'Arts of the contact zone', in D. Bartholomae \& A. Petrosky. (eds.) Ways of reading: An anthology for writers. 5th ed. New York: Bedford/St Martins. 
Thesen

Soudien, C. 2012. Realising the dream. Cape Town: HSRC Press.

Thesen, L. \& E. van Pletzen. (eds.) 2006. Academic literacies and the languages of change. London: Continuum.

Vera-Sanso, P. 2000. 'Risk-talk: The politics of risk and its representation', in P. Caplan. (ed.). Risk revisited. London: Pluto, 108-132.

Zinn, J.O. 2010. 'Risk as discourse: Interdisciplinary perspectives', Critical Analysis of Discourse Across Disciplines, 42(2): 106-124. 